\title{
PENGARUH FAKTOR FUNDAMENTAL TERHADAP RETURN SAHAM
}

\author{
Pandaya $^{1}$, Pujihastuti Dwi Julianti ${ }^{2}$, Imam Suprapta ${ }^{3^{*}}$ \\ 1,2,3 STIE Muhammadiyah Jakarta, pandaya965@gmail.com,djpuji8@gmail.com, \\ imamdosen@gmail.com(Corresponding Author)
}

\begin{abstract}
ABSTRAK
Tujuan dari penelitian ini adalah untuk menguji pengaruh faktor fundamental yang dilihat dari unsur EPS, PER, PBV, ROE, DER dan DPR terhadap Return Saham. Metode analisis yang digunakan adalah analisis regresi linier berganda. Penelitian ini menggunakan 21 perusahaan terdaftar di Index Stock Exchange (IDX) yang konsisten masuk dalam indeks LQ45 selama periode 2015 sampai dengan 2019. Penentuan sample dalam penelitian ini menggunakan metode purposive sampling. Berdasarkan analisis hasil penelitian bahwa EPS berpengaruh negatif signifikan terhadap return saham, PER dan PBV berpengaruh positif signifikan terhadap return saham, ROE dan DER tidak berpengaruh terhadap return saham dan DPR berpengaruh negatif terhadap return saham. Koefisien determinasi dari hasil penelitian dari enam variabel terhadap Return Saham sebesar 57,0424\% sedangkan sisanya 42,9576\% dipengaruhi oleh faktor lain yang tidak dimasukkan ke dalam model penelitian.
\end{abstract}

Kata kunci : Return Saham, EPS, PER, PBV, ROE, DER dan DPR

\begin{abstract}
The purpose of this study was to examine the effect of fundamental factors as seen from the elements of EPS, PER, PBV, ROE, DER and DPR on Stock Return. The analytical method used is multiple linear regression analysis. This study uses 21 companies listed on the Stock Exchange Index (IDX) that are consistently included in the LQ45 index during the 2015 to 2019 period. The determination of the sample in this study uses a purposive sampling method. Based on the analysis of the research results, EPS has a significant negative effect on stock returns, PER and PBV have a significant positive effect on stock returns, ROE and DER do not have a significant effect on stock returns and $D P R$ has a negative effect on stock returns. The coefficient of determination from the research results of the six variables on Stock Returns is $57.0424 \%$ while the remaining $42.9576 \%$ is influenced by other factors that are not included in the research model.
\end{abstract}

Keywords : Stock Return, EPS, PER, PBV, ROE, DER and DPR

Naskah diterima: 16-11-2020, Naskah dipublikasikan: 30-11-2020

\section{PENDAHULUAN}

Pasar modal (capital market) merupakan pasar untuk berbagai instrumen keuangan jangka panjang yang bisa diperjualbelikan, baik surat utang (obligasi), ekuiti (saham), reksa dana, instrumen derivatif maupun instrumen lainnya. Pasar modal merupakan sarana pendanaan bagi perusahaan maupun institusi lain (misalnya pemerintah), dan sebagai sarana bagi kegiatan berinvestasi. Dengan demikian, pasar modal memfasilitasi berbagai sarana dan prasarana kegiatan jual beli dan kegiatan terkait lainnya. Instrument keuangan (produk) yang diperdagangkan di Pasar Modal Indonesia antara lain adalah saham, surat utang (obligasi), reksa dana, exchange traded fund (ETF) dan derivatif (idx.co.id).

Diantara instrument keuangan yang diperdagangkan di pasar modal Indonesia, saham merupakan produk yang paling banyak diminati karena tingkat return yang dihasilkan lebih tinggi. Salah satu indeks saham yang paling digemari investor adalah Indeks LQ45, yaitu Indeks yang 


\section{JURNAL AKUNTANSI, Vol. 9, No. 2, November (2020)}

mengukur empat puluh lima saham dengan likuiditas tinggi dan kapitalisasi pasar yang besar serta didukung oleh kinerja fundamental perusahaan yang baik sehingga dianggap mampu menghasilkan return yang diharapkan investor. Namun Indeks LQ45 juga tidak menjamin return yang akan didapatkan investor akan terus meningkat. Seperti yang digambarkan pada grafik rata-rata return tahun 2015 sampai dengan 2019 di bawah ini.

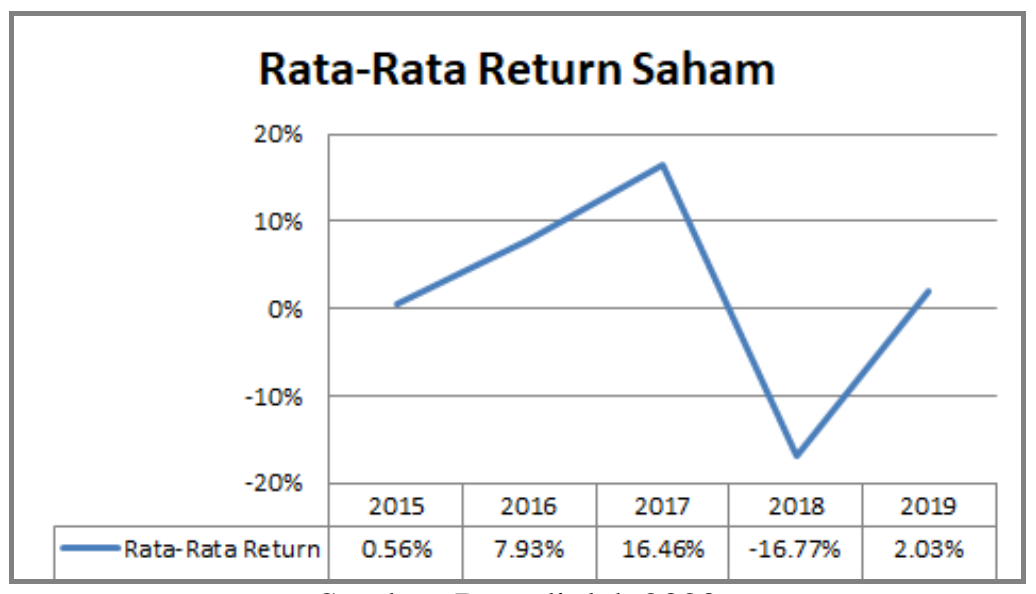

Sumber. Data diolah 2020

Gambar 1. Grafik rata-rata terurn saham yang konsisten masuk dalam Indeks LQ45 Tahun 2015-2019

Gambar 1. Memperlihatkan return saham yang fluktuatif di tahun 2015 sampai dengan 2019. Pada dasarnya saham bersifat high risk high return, yang dapat diartikan bahwa semakin tinggi return maka semakin tinggi juga risiko yang akan di dapatkan. Oleh sebab itu, setiap investor harus melakukan analisis yang tepat agar risiko yang tidak diharapkan dapat diminimalisir. Analisis yang dapat dilakukan antara lain adalah analisis teknikal dan fundamental. Umumnya pengguna analisis fundamental adalah investor jaka panjang, karena dengan analisis fundamental investor dapat mengetahui apakah perusahaan tersebut sehat atau tidak.

Menurut Munfaridah (2012) analisis fundamental adalah analisis yang didasarkan pada fundamental ekonomi suatu perusahaan yang terdapat dalam laporan keuangan. Teknik ini menitik beratkan pada rasio finansial dan kejadian-kejadian yang secara langsung maupun tidak langsung mempengaruhi kinerja keuangan. Penelitian ini menggunakan informasi keungan perusahaan sebagai salah satu paremeter yang bisa digunakan dalam memperkirakan return saham. Diharapkan dengan semakin baiknya kinerja keuangan perusahaan maka harga saham juga akan meningkat dan memberikan return yang tinggi untuk investor. Dalam menganalisis kinerja keuangan penelitian ini menggunakan beberapa rasio keuangan diantaranya PER, EPS, ROE, PBV, DER, DPR.

Penelitian yang dilakukan oleh Mayuni \& Suarjaya (2018) mengungkapkan bahwa EPS berpengaruh positif terhadap return saham sedangkan menurut Novitasari (2013) dan Anwaar (2016), bahwa EPS berpengaruh negatif terhadap return saham. Penelitian berbeda dilakukan oleh Himmatussuhra, dkk (2018) dan Mahpudin \& Annisa (2018) bahwa EPS tidak berpengaruh terhadap return saham. Penelitian yang dilakukan oleh Ni'mah (2017), Siregar (2018), menyatakan bahwa PER berpengaruh positf terhadap return saham. Penelitian yang dilakukan oleh Permata (2015) menyatakan PER berpengaruh negatif terhadap return saham sedangkan menurut Carlo (2014) PER tidak berpengaruh terhadap return saham.

Menurut Purnamaningsih \& Wirawati (2014), PBV berpengaruh positif terhadap return saham, menurut Silvatika (2012) bahwa PBV berpengaruh negatif terhadap retutn saham, sedangkan menurut Mahpudin \& Annisa (2018) dan Hermawan (2016) PBV tidak mempengaruhi return saham. Penelitian yang dilakukan oleh Carlo (2014), Siregar (2018) menunjukan bahwa ROE berpengaruh positif terhadap return saham, menurut Anwaar (2016) ROE berpengaruh negatif sedangkan menurut Sari, dkk (2013) ROE tidak mempengaruhi return saham. 
Menurut Susilowati, dkk (2019) DER berpengaruh positif terhadap return saham sedangkan Supadi \& Amin (2012) dan Hermawan (2016) mengemukakan bahwa DER berpengaruh negatif terhadap return saham. Penelitian sebelumnya juga dilakukan oleh Setiyono, dkk (2018), Widyastuti \& Andamari (2013), bahwa DER tidak mempengaruhi return saham. Penelitian yang dilakukan oleh Carlo (2014), bahwa DPR berpengaruh positif terhadap return saham. Menurut Pratiwi (2015) DPR berpengaruh negative terhadap return saham. Penelitian berbeda dilakukan oleh Devaki (2017) dan Wardhani (2012), bahwa DPR tidak berpengaruh terhadap return saham.

Berdasarkan latar belakang tersebut, penelitian-penelitian terdahulu masih menghasilkan banyak perbedaan, maka perlu dilakukan penelitian kembali tentang pengaruh PER, EPS, ROE, PBV, DER, DPR terhadap return saham. Penelitian ini bertujuan untuk menguji dan menemukan bukti secara empiris mengenai pengaruh faktor fundamental yang di lihat dengan PER, EPS, ROE, PBV, DER, DPR terhadap return saham.

\section{KAJIAN LITERATUR \\ Analisis Fundamental}

Analisis fundamental adalah analisis saham yang mengutamakan pendekatan intrinsic value (nilai saham) dengan berdasarkan faktor ekonomi dan keuangan berbasis kualitatif dan kuantitatif. Inti dari analisis fundamental adalah menemukan apakah harga saham saat ini terlalu mahal (overprice) atau cukup murah (underprice) sehingga menentukan keputusan jual atau beli saham (Jefferson \& Sudjatmoko, 2013). Analisis fundamental merupakan teknik analisis saham yang mempelajari tentang keuangan mendasar dan fakta ekonomi dari perusahaan sebagai langkah dari penilaian harga saham perusahaan (Gumandi, 2011).

\section{Earning Per Share (EPS)}

EPS atau rasio laba per lembar saham merupakan rasio untuk mengukur keberhasilan manjemen dalam mencapai keuntungan bagi pemegang saham. EPS yang mengalami kenaikan setiap tahunnya menandakan bahwa perusahaan terus tumbuh dan berkembang. Laba per lembar saham bergantung dengan jumlah laba yang dibagikan dan juga berapa banyak lembar saham yang beredar. Dari perspektif investor, semakin tinggi EPS semakin baik, karena ini menunjukkan prospek masa depan bisnis perusahaan, peluang pertumbuhan potensial dan pengembalian yang lebih tinggi bagi investor

Menurut Haque \& Faruquee (2013) EPS adalah jumlah laba setelah pajak dibagi jumlah total saham yang beredar.

$$
\text { Earning Per Share }=\frac{\text { laba setelah pajak }}{\text { jumlah total saham yang beredar }}
$$

\section{Price Earning Ratio (PER)}

PER umumnya dikaitkan dengan kecepatan pengembalian investasi. Menurut Filbert \& Prasetya (2017) PER adalah salah satu rasio dalam menghitung nilai valuasi atas harga saham. Komponen dari PER adalah :

$$
\begin{aligned}
\text { Price Earning Ratio } & =\frac{\text { Harga Saham Saat Itu }}{\text { Keuntungan per Lembar Saham }} \\
\text { Atau } & \\
\text { Price Earning Ratio } & =\frac{\text { Price }}{\text { Earning per Share }}
\end{aligned}
$$

\section{Price Book Value (PBV)}

PBV adalah rasio pasar yang digunakan untuk mengukur kinerja harga pasar saham terhadap nilai bukunya (Azis dkk, 2015). PBV dihitung dengan : 


\section{Return On Equity (ROE)}

$$
\text { Price Book Value }=\frac{\text { Harga Saham }}{\text { Book Value }}
$$

Menurut Anwaar (2016) Return On Equity adalah indikasi seberapa menguntungkan perusahaan dengan membandingkan laba bersihnya dengan ekuitas rata-rata pemegang saham. Wang, Fu \& Luo, (2013) menghitung nilai laba atas ekuitas dengan rumus di bawah ini:

$$
\text { Return On Equity }=\frac{\text { Net Profit }}{\text { Average Net Assets }}
$$

\section{Debt to Equity Ratio (DER)}

Menurut Hartono (2018) DER adalah rasio yang menunjukan sejauh mana modal sendiri menjamin seluruh utang. Rasio ini juga dianggap sebagai perbandingan antara dana pihak luar dengan dana pemilik perusahaan. Melalui rasio ini dapat diketahui seberapa besar utang digunakan untuk mengangkat nilai asset.

Menurut Hartono (2018) DER dapat dicari dengan rumus :

$$
\text { Debt to Equity Ratio }(D E R)=\frac{\text { Total Utang }}{\text { Total Modal Sendiri }}=\frac{\text { Total Debt }}{\text { Total Equity }}
$$

\section{Dividend Payout Ratio (DPR)}

Menurut Tambunan (2008) DPR adalah persetase dividen yang dibayarkan yang diambil dari laba bersih. Dividend Payot Ratio (DPR) melihat bagian earning laba yang dibayarkan sebagai deviden kepada investor.

Menurut (Oladipupo \& Okafor, 2013) DPR dapat dihitung menggunakan rumus:

$$
\text { Devidend Payout Ratio }=\frac{\text { Devidend Per Share }}{\text { Earning Per Share }}
$$

\section{Return Saham}

Menurut Jogiyanto (2013) return saham merupakan hasil ekspetasi yang diharapkan oleh investor. Return saham diperoleh dari penanaman modal yang terdiri dari:

a. Capital gain (loss)

Capital gain (loss) yaitu keuntungan atau kerugian yang didasarkan pada penutupan harga saham periode sekarang dengan periode sebelumnya

$$
\text { Capital Gain (loss) }=\frac{P_{t}-P_{t-1}}{P_{t-1}}
$$

Keterangan :

Pt = Harga saham periode sekarang

Pt-1 = Harga saham periode sebelumnya

b. Yield

Yield merupakan presentase penerimaan kas periode tertentu terhadap harga investasi dan untuk saham biasa dimana pembayaran periodik sebesar Dt rupiah per lembar :

$$
\text { Yield }=\frac{D t}{P_{t-1}}
$$

Keterangan :

$\mathrm{Dt}=$ Deviden kas yang dibayarkan

Pt-1 = Harga saham periode sebelumya 
Istilah Yield lebih sering digunakan pada obligasi karena hasil dari obligasi berbentuk uang tambahan yang tidak mengurangi nilai pokoknya (Zulfikar, 2016). Dalam investasi saham memang terkadang ada pembagian deviden, namun tidak semua perusahaan melakukan pembagian dividen kas secara periodik kepada pemegang sahamnya.

Maka penelitian ini mengugunakan rumus return saham menurut Menurut Jogiyanto (2013:206) :

Capital Gain (loss) $=\frac{P_{t}-P_{t-1}}{P_{t-1}}$

Keterangan :

$\mathrm{Pt}=$ Harga saham periode sekarang

Pt-1 = Harga saham periode sebelumnya

\section{Pengembangan Hipotesis}

EPS atau laba per lembar saham adalah tingkat keuntungan bersih untuk tiap lembar saham yang mampu diraih perusahaan pada saat menjalankan operasinya. Jika EPS perusahaan mengalami kenaikan pada setiap tahunnya, menandakan perusahaan terus berkembang dan bertumbuh. Oleh sebab itu, EPS dianggap investor mampu menggambarkan laba perusahaan selama satu periode laporan keuangan untuk setiap lembar sahamnya (Filbert \& Prasetya, 2017). Laba perusahaan yang tinggi akan meningkatkan return saham yang di dapat oleh investor. Penelitian yang dilakukan oleh Mayuni \& Suarjaya (2018) yang mengungkapkan bahwa EPS berpengaruh positif terhadap return saham. Berdasarkan uraian tersebut maka hipotesis pertama dalam penelitian ini adalah

\section{$\mathrm{H}_{1}$ : EPS berpengaruh positif terhadap return saham}

Menurut Masa'deh dkk (2015) PER merupakan hasil perbandingan antara harga per lembar saham dengan pendapatan per lembar saham. Menurut Filbert \& Prasetya (2017) nilai PER yang kecil menunjukkan harga saham tersebut murah untuk dibeli oleh investor, hal tersebut juga mengindikasikan semakin baik pula kinerja per lembar saham perusahaan dalam menghasilkan laba. Sehingga semakin kecil PER makan akan meningkatkan return saham. Penelitian yang dilakukan Permata (2015), menyatakan bahwa PER berpengaruh negatif terhadap return saham. Berdasarkan uraian tersebut maka hipotesis kedua dalam penelitian ini adalah :

\section{$\mathrm{H}_{2}$ : PER berpengaruh negative terhadap return saham}

PBV memberikan perbandingan harga saham dengan nilai buku per lembar saham. Harga saham yang semakin tinggi di pasar akan mendapat penilaian baik dari investor. Penilaian yang baik akan menarik investor melakukan pembelian saham sehingga harga saham meningkat dan return yang diterima investor meningkat (Dwialesi \& Darmayanti, 2016). Hal ini di dukung oleh penelitian yang dilakukan oleh Purnamaningsih \& Wirawati (2014), yang menyatakan bahwa PBV berpengaruh positif terhadap return saham. Berdasarkan uraian tersebut maka hipotesis ketiga dalam penelitian ini adalah :

\section{$\mathrm{H}_{3}$ : PBV berpengaruh positif terhadap return saham}

ROE merupakan salah satu cara untuk menghitung efesiensi perusahaan dengan cara membandingkan antara laba yang tersedia bagi pemilik modal sendiri dengan jumlah modal sendiri yang menghasilkan laba tersebut (Azis, dkk., 2015). ROE merupakan rasio yang dipergunakan oleh investor guna melihat tingkat pengembalian terhadap modal yang mereka tanamkan (Nelia \& Widyawati, 2014). Semakin besar rasio ROE maka semakin besar tingkat pengembalian (return) yang akan diperoleh oleh pemegang saham. Kenaikan nilai ROE ditunjukkan apabila laba bersih yang diperoleh perusahaan semakin besar dan sebaliknya jika laba bersih semakin kecil maka nilai ROE semakin kecil. Hal ini sejalan dengan penelitian yang dilakukan oleh Carlo (2014) dan Siregar (2018) yang menunjukan bahwa ROE berpengaruh positif terhadap return saham. Berdasarkan uraian tersebut maka hipotesis keempat dalam penelitian ini adalah :

\section{$\mathrm{H}_{4}$ : ROE berpengaruh positif terhadap return saham}




\section{JURNAL AKUNTANSI, Vol. 9, No. 2, November (2020)}

DER digunakan untuk mengetahui berapa besar hutang yang dimiliki perusahaan bila dibandingkan dengan ekuitasnya. Menurut Setiyono, dkk (2018) rasio ini mengambarkan kemampuan perusahaan untuk melunasi kewajibannya. Semakin tinggi angka rasionya menandakan semakin besar pembiayaan yang di lakukan dengan hutang. Besarnya beban kewajiban yang ditanggung oleh manajemen dapat mengurangi jumlah laba perusahaan yang selanjutnya dapat berpengaruh terhadap penurunan harga serta return sahamnya. Penelitian yang dilakukan oleh Supadi \& Amin (2012) dan Hermawan (2016) mengemukakan bahwa DER berpengaruh negatif terhadap return saham. Berdasarkan uraian tersebut maka hipotesis kelima dalam penelitian ini adalah :

\section{$\mathrm{H}_{5}$ : DER berpengaruh negatif terhadap return saham}

DPR merupakan rasio yang mengukur seberapa besar tingkat pembagian dividen yang dibagikan kepada pemegang saham. Menurut Jogiyanto (2010) semakin besar dividen yang dibayarkan maka semakin besar pula harga saham. Harga saham yang semakin tinggi akan meningkatkan return yang didapatkan. Hal ini sejalan dengan penelitian yang dilakukan oleh Carlo (2014), bahwa DPR berpengaruh positif terhadap return saham. Berdasarkan uraian tersebut maka hipotesis keenam dalam penelitian ini adalah :

\section{$\mathrm{H}_{6}$ : DPR berpengaruh positif terhadap return saham}

Berdasarkan uraian diatas, kerangka pemikiran penelitian ini adalah :

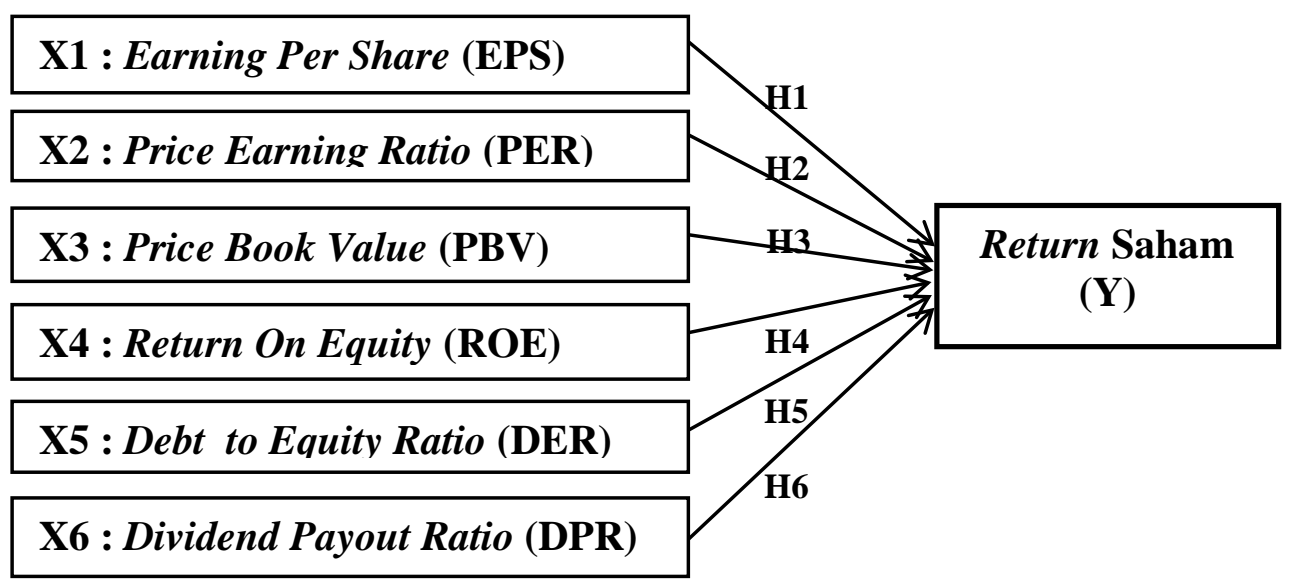

Gambar 2. Kerangka Pemikiran

\section{METODE PENELITIAN}

Penelitian ini menggunakan data sekunder yaitu data time series dan laporan keuangan perusahaan yang terdaftar dalam indeks LQ45 pada Bursa Efek Indonesia selama 5 tahun dengan periode 2015-2019 dengan kriteria-kriteria sebagai berikut :

\section{Tabel 1. Pengambilan Sampel}

\begin{tabular}{|l|c|}
\hline \multicolumn{1}{|c|}{ Kriteria } & Jumlah \\
\hline Perusahaan yang terdaftar dalam Indeks LQ45 pada Bursa Efek Indonesia (BEI) & 45 \\
\hline $\begin{array}{l}\text { Perusahaan yang tidak konsisten masuk dalam Indeks LQ 45 selama periode 2015- } \\
\text { 2019. }\end{array}$ & $(17)$ \\
\hline $\begin{array}{l}\text { Perusahaan Indeks LQ 45 yang tidak mempublikasikan laporan keuangan tahunan } \\
\text { secara lengkap selama periode 2015-2019. }\end{array}$ & $(0)$ \\
\hline $\begin{array}{l}\text { Perusahaan Indeks LQ 45 yang melakukan stock split selama periode 2015-2019. } \\
\text { Perusahaan yang menggunakan mata uang asing dalam laporan keuangan selama } \\
\text { periode 2015-2019. }\end{array}$ & $(4)$ \\
\hline \multicolumn{1}{c}{ Total } & 21 \\
\hline
\end{tabular}

Sumber : diolah, 2020

Model penelitian ini adalah sebagai berikut : 
Model :

$$
\mathrm{RS}=\alpha+\beta_{1 \mathrm{a}} \mathrm{EPS}+\beta_{1 \mathrm{~b}} \mathrm{PER}+\beta_{1 \mathrm{c}} \mathrm{PBV}+\beta_{1 \mathrm{~d}} \mathrm{ROE}+\beta_{1 \mathrm{e}} \mathrm{DER}+\beta_{1 \mathrm{f}} \mathrm{DPR}+\mathrm{e}
$$

Keterangan :

$$
\begin{array}{ll}
\mathrm{RS} & =\text { Return Saham } \\
\mathrm{A} & =\text { Nilai konstanta } \\
\beta_{1} & =\text { Koefisien Regresi } \\
\mathrm{EPS} & =\text { Earning Per Share } \\
\mathrm{PER} & =\text { Price Earning Ratio } \\
\mathrm{PBV} & =\text { Price Book Value } \\
\mathrm{ROE} & =\text { Return On Equity } \\
\mathrm{DER} & =\text { Debt to Equity Ratio } \\
\mathrm{DPR} & =\text { Dividend Payot Ratio } \\
\mathrm{e} & =\text { Error }
\end{array}
$$

Keputusan menerima atau menolak hipotesis yang diajukan dilakukan dengan syarat sebagai berikut :

a. Jika $t_{\text {hitung }}>\mathrm{t}_{\text {tabel }}$ maka hipotesis nol $\left(\mathrm{H}_{0}\right)$ ditolak atau $\mathrm{H}_{\mathrm{a}}$ diterima, artinya terdapat pengaruh antara dua variabel secara statistik.

b. Jika $\mathrm{t}_{\text {hitung }}<\mathrm{t}_{\text {tabel }}$ maka hipotesis nol $\left(\mathrm{H}_{0}\right)$ diterima atau $\mathrm{H}_{\mathrm{a}}$ ditolak, artinya tidak terdapat pengaruh antara dua variabel secara statistik.

\section{HASIL DAN PEMBAHASAN}

Berdasarkan hasil perhitungan statistik deskriptif variabel EPS, PER, PBV, DPR, ROE dan DER maka dapat dijelaskan (Tabel 2) sebagai berikut:

a. Variabel EPS memiliki nilai minimum -19,76 pada Bank Tabungan Negara (Persero) Tbk. tahun 2019 dan nilai maxsimum 5.654,99 pada Gudang Garam Tbk. tahun 2019. Nilai rata-rata (mean) sebesar 638,04 dan standar deviasi sebesar 942,45.

b. Variabel PER memiliki nilai minimum sebesar 6 pada Media Nusantara Citra Tbk. dan Waskita Karya (Persero) Tbk. tahun 2018, nilai maxsimum sebesar 107 Bank Tabungan Negara (Persero) Tbk. tahun 2019, nilai rata-rata (mean) sebesar 21 dan standar deviasi sebesar 14.

c. Variabel PBV memiliki nilai minimum sebesar 1 dan nilai maxsimum sebesar 82, nilai rata-rata (mean) sebesar 14 dan standar deviasi sebesar 14.

d. Variabel ROE memiliki nilai minimum sebesar 0,01 pada Bank Tabungan Negara (Persero) Tbk. tahun 2019 dan nilai maxsimum sebesar 2,81 pada Matahari Departement Store Tbk. tahun 2015, nilai rata-rata (mean) sebesar 0,26 dan standar deviasi sebesar 0,40

e. Variabel DER memiliki nilai terendah minimum sebesar 0,15 pada Indocement Tunggal Prakarsa Tbk. tahun 2016 dan nilai maxsimum sebesar 11,40 pada Bank Tabungan Negara (Persero) Tbk. tahun 2015, nilai rata-rata (mean) sebesar 2,05 dan standar deviasi sebesar 2,47

f. Variabel DPR memiliki nilai minimum 0,04 pada Bumi Serpong Damai Tbk. tahun 2017 dan 2019. nilai maxsimum 2,68 pada Bank Tabungan Negara (Persero) Tbk. tahun 2015. Nilai ratarata (mean) sebesar 0,54 dan standar deviasi sebesar 0,45

Tabel 2. Deskripsi Variabel Penelitian

\begin{tabular}{|c|r|r|r|r|}
\hline \multirow{2}{*}{ Variabel } & \multicolumn{4}{|c|}{$\mathbf{N}=\mathbf{1 0 5}$} \\
\cline { 2 - 5 } & \multicolumn{1}{|c|}{ MIN } & \multicolumn{1}{c|}{ MAX } & \multicolumn{1}{c|}{ MEAN } & \multicolumn{1}{c|}{ ST. DEV } \\
\hline EPS & 19,76 & $5.654,99$ & 638,04 & 942,45 \\
\hline PER & 6 & 107 & 21 & 14 \\
\hline PBV & 1 & 82 & 6 & 14 \\
\hline ROE & 0,01 & 2,81 & 0,26 & 0,40 \\
\hline DER & 0,15 & 11,40 & 2,05 & 2,47 \\
\hline DPR & 0,04 & 2,68 & 0,54 & 0,45 \\
\hline
\end{tabular}

Sumber: Data IDX diolah, 2020 


\section{JURNAL AKUNTANSI, Vol. 9, No. 2, November (2020)}

\section{Analisis Regresi Linier Berganda}

Hasil pengujian terbaik adalah dengan Fixed Effect Model dengan menggunakan General Least Square (Weighted cross section). Berikut hasil regresi fixed effect weight model yang ditunjukkan pada tabel 3. sebagai berikut:

Tabel 3. Hasil Regresi Fixed Effect Weight Model

\begin{tabular}{crrrr}
\hline \hline Variable & Coefficient & Std. Error & t-Statistic & Prob. \\
\hline \hline C & 0.078667 & 0.165804 & 0.474456 & 0.6365 \\
EPS & -0.000178 & $8.90 \mathrm{E}-05$ & -1.995760 & 0.0495 \\
PER & 0.011622 & 0.003657 & 3.178260 & 0.0021 \\
PBV & 0.010603 & 0.004671 & 2.269981 & 0.0260 \\
ROE & -0.055616 & 0.083389 & -0.666945 & 0.5068 \\
DER & -0.033895 & 0.064155 & -0.528332 & 0.5988 \\
DPR & -0.310541 & 0.085369 & -3.637618 & 0.0005
\end{tabular}

Sumber: Eviews, data diolah, 2020

Berdasarkan hasil pengujian yang ditunjukkan pada Tabel 3., maka dapat disimpulkan persamaan regresi linear berganda dalam penelitian ini sebagai berikut:

Dari persamaan regresi linear berganda yang digunakan dalam penelitian ini dapat dijelaskan sebagai berikut :

a. Konstanta dengan nilai sebesar 0.078667 menunjukkan bahwa jika semua variabel independen bernilai nol (0) maka return saham bernilai 0.078667 .

b. Koefisien EPS sebesar -0.000178 artinya jika EPS mengalami kenaikan sebesar 1\% maka return saham akan turun sebesar 0.000178 . Koefisien bernilai negatif artinya terjadi hubungan yang negative antara EPS dengan return saham.

c. Koefisien PER sebesar 0.011622 artinya menunjukkan jika PER mengalami kenaikan sebesar $1 \%$ maka return saham akan naik sebesar 0.011622 . Koefisien bernilai positif artinya terjadi hubungan yang positif antara PER dengan return saham atau terdapat korelasi positif.

d. Koefisien PBV sebesar 0.010603 artinya menunjukkan jika PBV mengalami kenaikan sebesar $1 \%$ maka return saham akan naik sebesar 0.010603 . Koefisien bernilai positif artinya terjadi hubungan yang positif antara PBV dengan return saham atau terdapat korelasi positif.

e. Koefisien ROE sebesar -0.055616 artinya menunjukkan jika ROE mengalami kenaikan sebesar $1 \%$ maka return saham akan mengalami penurunan sebesar 0.055616. Koefisien bernilai negatif artinya terjadi hubungan yang negative antara ROE dengan return saham.

f. Koefisien DER sebesar -0.033895 artinya menunjukkan jika DER mengalami kenaikan sebesar $1 \%$ maka return saham akan turun sebesar 0.033895. Koefisien bernilai negatif artinya terjadi hubungan yang negative antara DER dengan return saham atau terdapat korelasi negative.

g. Koefisien DPR sebesar -0.31054 artinya menunjukkan jika DPR mengalami kenaikan sebesar $1 \%$ maka return saham akan turun sebesar 0.31054 . Koefisien bernilai negatif artinya terjadi hubungan yang negative antara DPR dengan return saham.

\section{Uji Hipotesis}

\section{Uji Statistik t}

Dalam mencari df (n-k) dalam penelitian ini yaitu 21 (21-7) dimana $n$ sebesar 21 yang merupakan jumlah observasi dan $\mathrm{k}=7$ merupakan jumlah variabel dependen (terikat) dan variabel independen (bebas). Dengan nilai df 14 dan signifikansi 0,05, maka nilai t tabel adalah 1,76131.

Untuk mengetahui pengaruh secara parsial antara variabel dependen dengan variabel independen yaitu dengan menggunakan kriteria pengujian apabila $\left(t_{\text {hitung }}>t_{\text {tabel }}\right)$ atau $(p$-value $<0,05)$ maka variabel independen berpengaruh terhadap variabel dependen.

\section{Uji Koefisien Determinasi}


Berdasarkan hasil pengujian yang ditunjukkan oleh tabel 4.4 diketahui bahwa hasil Adjusted R-squared adalah 0.570424 atau 57,0424 \%. Hal ini berarti bahwa variabel dependen return saham dapat dijelaskan variabel Independen yaitu EPS, PER, PBV, ROE, DER dan sebesar 57,0424\%. Sedangkan 42,9576\% lainnya dipengaruhi atau dijelaskan oleh variabel-variabel lainnya diluar model regresi.

Berikut hasil pengujian koefisien determinasi $\left(\mathrm{R}^{2}\right)$ yang telah dilakukan:

Tabel 4. Hasil Uji Koefisien Determinasi

Weighted Statistics

\begin{tabular}{crcc}
\hline \hline Root MSE & 0.258314 & R-squared & 0.677818 \\
Mean dependent var & -0.027752 & Adjusted R-squared & 0.570424 \\
S.D. dependent var & 0.467529 & S.E. of regression & 0.299706 \\
Sum squared resid & 7.006228 & F-statistic & 6.311500 \\
Durbin-Watson stat & 2.346425 & Prob(F-statistic) & 0.000000 \\
\hline \hline
\end{tabular}

Sumber: Eviews, data diolah, 2020

\section{PENUTUP}

EPS berpengaruh negative secara signifikan terhadap return saham, hipotesis pertama ditolak. Hasil penelitian didukung hasil penelitian terdahulu diantaranya Novitasari (2013) dan Anwaar (2016), dengan hasil EPS berpengaruh negatif terhadap return saham. Artinya jika EPS naik maka return saham akan turun. Hal ini disebabkan jumlah saham yang beredar akan berpengaruh besar terhadap laba per lembar saham. Karena keuntungan perusahaan akan dibagikan ke seluruh lembar saham yang diterbitkan oleh perusahaan. Sehingga investor akan beranggapan tingginya laba per lembar saham pada suatu perusahaan tidak selalu menunjukkan kinerja lebih baik dibandingkan dengan perusahaan lain.

PER berpengaruh positif terhadap return saham, hipotesis kedua ditolak. Hasil penelitian ini didukung oleh penelitian sebelumnya yang dilakukan oleh Ni'mah (2017), Siregar (2018) yang menyatakan bahwa PER berpengaruh positif terhadap return saham. Artinya semakin besar PER maka harga saham terhadap pendapatan per lembar saham juga akan meningkat hal ini membuat return yang akan di dapatkan investor pun meningkat. Sehingga, semakin tinggi nilai PER dari suatu perusahaan, investor semakin optimis dalam memandang prospek return saham yang akan di peroleh. Dan sebaliknya, semakin rendah nilai PER maka pasar semakin merasa cemas dan pesimis mengenai return saham yang akan di dapatkan.

PBV berpengaruh positif terhadap return saham, hipotesis ketiga diterima. Hasil penelitian ini di dukung oleh penelitian terdahulu yang dilakukan oleh Purnamaningsih \& Wirawati (2014) menyatakan, PBV berpengaruh positif terhadap return saham. Semakin tinggi PBV semakin besar kepercayaan pasar terhadap perusahaan, sehingga permintaan saham perusahaan akan meningkat dan akan mendorong harga saham, return saham yang diperoleh pun meningkat.

ROE tidak berpengaruh terhadap return saham, hipotesis keempat di tolak. Hasil penelitian ini didukung oleh penelitian sebelumnya yang dilakukan oleh Novitasari, dkk (2013), menunjukan bahwa ROE tidak berpengaruh terhadap return saham. Rendahnya ROE tidak akan mempengaruhi investor dalam pengambilan keputusan investasi. Karena tidak semua perusahaan dengan modal menurun akan berpengaruh pada return saham, seperti perusahaan kecil yang lebih cenderung memiliki ROE yang terus meningkat sejalan dengan penambahan laba bersih.

DER tidak berpengaruh terhadap return saham, hipotesis kelima ditolak. Hasil Penelitian ini didukung oleh penelitian sebelumnya yang dilakukan oleh Widyastuti \& Andamari (2013), DER tidak berpengaruh terhadap return saham. Artinya hutang tidak menjadi tolak ukur investor, karena investor akan lebih mempertimbangkan pihak manajemen dalam mengelola dana tersebut. 


\section{JURNAL AKUNTANSI, Vol. 9, No. 2, November (2020)}

DPR berpengaruh negative terhadap return saham, hipotesis keenam ditolak. Penurunan pembagian deviden dari waktu ke waktu dapat meningkatkan return saham. Hal ini di dukung oleh penelitian yang dilakukan oleh Sari (2012), perusahaan dengan pertumbuhan lambat akan cenderung menggunakan deviden yang lebih tinggi untuk mengatasi potensi overinsvestment.

\section{REFERENSI}

Anwaar, M. (2016). Impact of firms performance on stock returns (evidence from listed companies of ftse-100 index London, UK). Global Journal of Management and Business Research.

Azis, M., Mintarti, S., \& Nadir, M. (2015). Manajemen Investasi : Fundamental, Teknikal, Pelaku Investor dan Return Saham. Deepublish : Yogyakarta

Carlo, M. A. (2014). Pengaruh Return On Equity, Dividend Payout Ratio dan Price to earning Ratio Pada Return Saham. E-Jurnal Akuntansi, 150-164

Devaki, A. (2017) Fakor-Faktor yang Mempengaruhi Return Saham pada Perusahaan LQ45 di Bursa Efek Indonesia. Jurnal Benefita: Ekonomi Pembangunan, Manajemen Bisnis \& Akuntansi, 2 (2), 157-168

Dwialesi, J. B. \& Darmayanti, N. P. A. (2016). Pengaruh Faktor-Faktor Fundamental Terhadap Return Saham Indeks Kompas 100. E-Jurnal Manajemen, 5(4).

Filbert, R. \& Prasetya, W. (2017). Investasi Saham ala Fundamentalis Dunia. PT. Gramedia : Jakarta

Gumandi, T. A. (2011). Manajemen Investasi. Jakarta: Mitra Wacana Media

Hartono. (2018). Konsep Analisa Laporan Keuangan Dengan Pendekatan Rasio dan SPSS. Ed.1, Cet. 1. Deepublih : Yogyakarta

Haque, S. \& Faruquee, M. (2013). Impact of Fundamental Factors on Stock Price: A Case Based Approach on Pharmaceutical Companies Listed with Dhaka Stock Exchange. International Journal of Business and Management Invention, Vol.2 (9). 34-41

Hermawan, W. A. (2016). Analisis Pengaruh Faktor Fundamental Terhadap Return Saham pada Perusahaan Properti dan real Estate di Bursa Efek Indonesia. Jurnal Manajemen Bisnis Indonesia (JMBI). 5(6), 641-647.

Himmatussuhra, Mardani, R. M., \& ABS, M. K. (2018). Pengaruh EPS, ROE, DER dan TATO terhadap Return Saham pada Perusahaan Perbankan yang Terdaftar di BEI. Jurnal Ilmiah Riset MAnajemen, 7 (14)

Jefferson, J. \& Sudjatmoko, N. (2013). Shopping Saham Modal Sejuta!. PT. Gramedia:Jakarta

Jogiyanto. 2010. Teori Portofolio dan Analisis Investasi. Yogyakarta: BPFEUGM.

Kariyoto (2017) Analisa Laporan Keuangan, Universitas Brawijaya Press. Malang

Mahpudin, E., \& Annisa, R. (2018). Analisis Pengaruh Faktor Fundamental Terhadap Return Saham (Studi Empiris pada Perusahaan Perbankan yang Terdaftar di BEI Periode 2013-2017). Accounthink: Journal of Accounting and Finance, 3 (02)

Masa'deh. R., Tayeh, M., Al-Jarrah, I. M., \& Tarhini, A. (2015). Accounting vs. Market-Based Measures or Form Peformance Related to Information Technology Investment. International Review of Social Sciences and Humanities, 9(1), 129-145.

Mayuni, I. A. I \& Suarjaya, G. (2018). Pengaruh ROA, Firm Size, EPS dan PER Terhadap Return Saham Pada Sektor Manufaktur di BEI. E-Jurnal Manajemen Unud. Vol. 7 No. 8

Munfaridah (2012). Analisis Pengaruh Faktor Fundamental Terhadap Return Saham Pada Perusahaan Sektor Aneka Industri Yan Terfdaftar di Bursa Efek Indonesia Tahun 2007-2010. Tugas Akhir Program Magister Universitas Terbuka : Jakarta

Nelia, I. A. \& Widyawati, N. (2014). Pengaruh Faktor Fundamental dan Risiko Sitematis Terhadap Return Saham Manufaktur. Jurnal dan Ilmu Riset Manajemen, 3(4).

Ni'mah, A. W. (2017). Analisis Pengaruh Faktor Fundamental Terhadap Return Saham Dengan Pengungkapan Corporate Social Responsibility (CSR) Sebagai Variabel Modersi. Skripsi Univertitas Islam Negeri Maulana Malik Ibrahim: Malang

Novitasari, R. (2013). Analisis Pengaruh Fundamental Terhadap Return Saham (Pada Perusahaan LQ45 Yang Terdaftar Di Bursa Efek Indonesia Tahun 2009-2012). Skripsi Fakultas Ekonomika dan Bisnis Universitas Diponegoro : Semarang 
Oladipupo, A. O \& Okafor, C.A. (2013). Relative Contribution of Working Capital Management to Corporate Profitability and Dividend Payout Ratio: Evidence From Nigeria. International Journal of Business and Finance Research, 3(2), 11-20

Permata, B. C. (2015). Pengaruh Faktor Fundamental Terhadap Return Saham Dengan Struktur Modal Sebagai Varibel Mediasi. Skripsi Universitas Negeri Yogyakarta

Purnamaningsih, D \& Wirawati, N.G. P. (2014). Pengaruh Return On Asset, Struktur Modal, Price to Book Value dan Good Corporate Governance Terhadap Return Saham. E-Jurnal Akuntansi, $1-16$.

Sari, E. I., (2013). Pengaruh Faktor-Faktor Fundamental Terhadap Harga Saham PT Unilever Indonesia Tbk . Jurnal Manajemen STIE MDP

Sari, R, N., (2012). Pengaruh Profitabilitas dan Kebijakan Dividen Terhadap Return Saham Perusahaan Manufaktur Dengan Nilai Perusahaan Sebagai Variabl Intervening Periode 20102014. Skripsi Universitas Negeri Yogyakarta

Sekaran, U., \& Bougie, R. (2014). Research Methods for Business. United Kingdom, West Sussex: John Wiley \& Sons Ltd.

Setiyono, W., Hariyani, D. S., Wijaya A. L., \& Apriyanti. (2018). Analisis Pengaruh Faktor Fundmental Terhadap Return Saham. Jurnal Kajian Akuntansi 2(2), 123-133.

Silvatika, B. A (2018). Financial Analisis Pengaruh Faktor Fundamental dan Teknikal Terhadap Return Saham. Jurnal Dinamika Manajemen dan Bisnis, 1(2)

Siregar, Y. N. (2018). Analisis Pengaruh Faktor Fundamental dan Risiko Sistematis Terhadap Return Saham Pada Saham LQ45 di Bursa Efek Indonesia. Skripsi Universitas Sumatera Utara: Medan

Sitompul, \& Sari, S. (2017). Analisis Pengaruh Kinerja Keuangan dan Ukuran Perusahaan Terhadap Harga Saham Pada Perusahaan Infrastructure, Utilities, dan Transportasi. Jurnal Ilmiah Manajemen, Vol 3 1-18.

Supadi, D. B. P. \& Amin, M. N. (2012). Pengaruh Faktor Fundamental dan Risiko Sistematis Terhadap return Saham Syariah. Media Riset Akuntansi, Auditing \& Informasi, 12(1), 23-24

Tambunan, A. P (2008). Menilai Harga Wajar Saham (Stock Valuation). PT. Gramedia : Jakarta

Wang, J., Fu, G. \& Luo, C. (2012). Accounting Information and Stock Price Reaction of Listed Companies - Evidence from Shangai Stock Exchange. Journal of Business \& Management, Volume 2, Issue 2 (2013), 11-21.

Wardhani, D. A. (2012). Reaksi Return Saham Terhadap Informasi Debt To Equity Ratio, Devidend Payout Ratio, Return On Asset dan Corporate Governance Perception Index Di Bursa Efek Indonesia 2006-2009. Jurnal Akuntansi Akutual, 1 (3), 186-194.

Wati, L.N (2018). Metodologi Penelitian Terapan : Aplikasi Spss, Eviews, Smart PLS, dan AMOS, Ed. Revisi. Pustaka Amri : Bekasi

Widyastuti, T., \& Andamari, B. G. (2013). Faktor Fundamental, Suku Bunga dan Nilai Tukar Terhadap Return Saham. Jurnal Akuntansi dan Auditing. 10(1), 13-28

Zulfikar. (2016). Pengantar Pasar Modal dengen pendekatan statistika. Ed.1, Cet 1. Deepublish: Yogyakarta

www.idx.co.id 